\title{
PEMBIAYAAN SYARIAH SEKTOR PERTANIAN
}

\author{
Faoeza Hafiz Saragih \\ Staf Pengajar Prodi Agribisnis Pertanian Universitas Medan Area \\ email: saragihhafiz@gmail.com
}

\begin{abstract}
Indonesia is an agriculture country, which means the agricultural sector was an important role in the Indonesian economy. One of the main problems faced by the agricultural sector is the lack of farmer capital in developing his farm, the farmer is not able to fund their farm with their own funds. The agricultural sector is known to be quite risky and uncertain and this make the financial institutions to fund this sector is relatively low. Other financing alternatives that may be the solution for farmers is the shariah financing institutions. Some shariah products which can be applied to agribusiness, among others: Mudharabah, Musharaka, muzara'ah, musaqoh, bai 'murabahah, bai istishna, bai' as-salam and rahn.
\end{abstract}

\section{Keyword: Agriculture, Financing, Shariah}

\section{PENDAHULUAN}

Indonesia adalah negara yang berlatar belakang agraris yang berarti sektor pertanian memegang peranan penting dalam perekonomian Indonesia. Adapun beberapa peran sektor pertanian antara lain sebagai penyerap tenaga kerja, kontribusi terhadap Pendapatan Domestik Bruto, sumber devisa, bahan baku industri, sumber bahan pangan dan gizi serta pendorong bergeraknya sektor-sektor ekonomi riil lainnya.

Pada akhir tahun 1990an sektor pertanian telah membuktikan sebagai sektor yang dapat menjadi penyangga perekonomian Indonesia dan samapi sekarang sektor pertanian masih dituntut berperan dalam pertumbuhan ekonomi. Namun sektor pertanian masih jauh dari kata "baik", fakta ini dapat dilihat dari taraf hidup petani yang rendah dan tidak mampunya produk pertanian Indonesia bersaing dipasar internasional. Maka dari sini timbul pertanyaan kenapa pertanian Indonesia tidak mampu berkembang seperti negara tetangga yaitu Thailand.

Salah satu permasalahan utama yang dihadapi sektor pertanian adalah keterbatasan permodalan dalam mengembangkan usaha pertaniannya. Kebutuhan akan modal diperkirakan akan meningkat setiap saat seiring dengan meningkatnya harga-harga saprodi pertanian. Permasalahannya adalah petani tidak sanggup mendanai usaha taninya dengan dana sendiri. Dengan keadaan seperti ini seharusnya peran lembaga keuangan swasta bisa cukup signifikan, terlalu mengandalkan peran pemerintah untuk membiayainya sangat riskan mengingat pemerintah harus membiayai sektor lainnya.

$\begin{array}{cclr}\text { Namun sektor pertanian yang } \\ \text { dikenal cukup } & \text { berisiko dan }\end{array}$


ketidakpastian (risky and uncertainty) membuat lembaga keuangan untuk mendanai sektor ini relatif rendah. Sebagai gambaran pada awal 1970-an alokasi kredit perbankan untuk sektor pertanian mencapai $27 \%$ (Soekartawi,1997), namun tahun 2005 turun menjadi hanya 5,3\% (Rp.37,2 triliyun) dari sejumlah Rp. 701,89 triliyun kredit perbankan (Bank Indonesia, 2006). Pembiayaan untuk sektor ini jauh dibawah pembiayaan untuk sektor perindustrian, perdagangan, jasa dan sektor perekonomian lainnya. Jika ada lembaga keuangan yang bersedia mengucurkan kredit ke sektor pertanian biasanya telah mengantisipasi dengan beberapa hal, diantaranya:

a. Menetapkan bunga yang cukup tinggi dan tetap.

b. Sangat selektif hanya membiayai usaha pada komoditas komersial yang bernilai tinggi.

c. Lebih memilih sebagai channeling bagi kredit program pemerintah.

Disamping itu terdapat tiga sifat dari kredit pertanian yang diberikan oleh lembaga keuangan, antara lain:

a. Dimana pinjaman harus dikembalikan ketika jatuh tempo, padahal sektor pertanian memiliki resiko kegagalan yang tinggi baik dalam produksi maupun fluktuasi harga yang relatif tinggi.

b. Adanya kesenjangan antara peminjam (debitor) dan pemberi pinjaman (kreditor), risiko kegagalan usaha hanya dibebankan kepada debitor sementara kreditor tetap mendapatkan keuntungan sebesar tingkat suku bunga yang ditetapkan.

c. Sistem pembiayaan pertanian selama ini diintegrasikan dengan pembiayaan sektor pertanian, yang apabila perhitungan dari sektor nonpertanian diterapkan pada sektor pertanian maka usaha pertanian akan cenderung over estimate.

Ciri khas kehidupan petani adalah pola penerimaan dan pengeluarannya. Pendapatan petani hanya diterima setiap musim panen sedangkan pengeluaran harus diadakan setiap hari, setiap minggu atau terkadang diwaktu yang sangat mendesak dimana masa panen belum tiba. Sehingga petani pada umumnya meminta pinjaman kepada kreditor nonformal (tengkulak), mengingat prosedur peminjaman yang sederhana, pencairan yang cepat dan tanpa agunan. Dibandingkan petani meminjam kepada kreditor formal (lembaga keuangan pemerintah/swasta) yang mempunyai prosedur peminjaman yang panjang sehingga pencairan dana yang lama disertai dengan agunan pula walau bunga yang ditawarkan lebih rendah dari kreditor nonformal.

Keadaan seperti ini terjadi diseluruh daerah pertanian di Indonesia dan menjadi lingkaran setan bagi petani sehingga kesejahteraan petani tidak juga membaik setiap waktu padahal telah kita ketahui bersama peran sektor pertanian sangatlah signifikan. Bagaimana sektor pertanian bisa menjadi lebih baik apabila para pelaku usaha tani tidak menjadi lebih baik pula.

Untuk itu perlu dilakukan alternatif pembiayaan yang lain yang 
dapat menjadi solusi permodalan bagi petani sehingga petani dapat mengembangkan usaha taninya. Salah satu model pembiayaan yang beberapa tahun terakhir ini mulai dimanfaatkan adalah lembaga pembiayaan syariah.

\section{PEMBAHASAN}

\section{Lembaga Pembiayaan Syariah}

Menurut syariah, hubungan pinjam meminjam tidak dilarang bahkan dianjurkan agar terjadi hubungan yang saling menguntungkan. Pinjam meminjam adalah akad sosial bukan akad komersial, artinya jika seseorang meminjam sesuatu tidak boleh disyaratkan untuk memberikan tambahan atas pokok pinjamannya. Setiap pinjaman yang menghasilkan manfaat dan bunga menurut pandangan syariat adalah riba dan riba itu haram, sehingga dalam lembaga pembiayaan syariah pinjaman tidak disebut kredit tetapi pembiayaan (financing).
Kelembagaan pembiayaan syariah adalah lembaga pembiayaan yang didalam menjalankan usahanya berlandaskan atas hokum-hukum syariah. Adapun secara teoritis ciri khas lembaga pembiayaan syariah antara lain a. Bebas bunga.

b. Berprinsip bagi hasil dan resiko (profit and risk sharing).

c. Perhitungan bagi hasil dilakukan pada saat transaksi berakhir, dimana dilakukan setelah ada keuntungan riil.

Perbedaan paling mendasar antara bank konvensional dan bank syariah adalah pada sistem bunga. Menurut Antonio (2004) sistem bunga pada bank konvensional dan syariah mempunyai kesamaan yaitu memberi keuntungan bagi pemilik modal. Namun terdapat perbedaan yang sangat banyak antara keduanya, yaitu:

\section{Tabel 1. Perbedaan antara sistem bunga dan bagi hasil}

\begin{tabular}{|c|c|}
\hline Sistem Bunga & Sistem Bagi Hasil \\
\hline $\begin{array}{l}\text { - Penentuan bunga dibuat pada } \\
\text { waktu akad dengan asumsi harus } \\
\text { selalu untung diatas bunga modal }\end{array}$ & $\begin{array}{l}\text { - Penentuan besarnya rasio/nisbah } \\
\text { bagi hasil dibuat pada waktu akad } \\
\text { dengan berpedoman pada } \\
\text { kemungkinan untung rugi }\end{array}$ \\
\hline $\begin{array}{l}\text { - Besarnya persentase berdasarkan } \\
\text { pada jumlah uang yang dipinjam }\end{array}$ & $\begin{array}{l}\text { - Besarnya rasio bagi hasil berdasarkan } \\
\text { pada jumlah keuntungan yang } \\
\text { diperoleh }\end{array}$ \\
\hline $\begin{array}{l}\text { - Pembayaran bunga tetap seperti } \\
\text { yang dijanjikan tanpa } \\
\text { pertimbangan apakah usaha yang } \\
\text { dijalankan oleh nasabah untung } \\
\text { atau rugi }\end{array}$ & $\begin{array}{l}\text { - Bagi hasil bergantung pada } \\
\text { keuntungan proyek yang dijalankan, } \\
\text { bila merugi maka kerugian akan } \\
\text { ditanggung bersama kedua belah } \\
\text { pihak }\end{array}$ \\
\hline $\begin{array}{l}\text { - Jumlah pembayaran bunga tidak } \\
\text { meningkat sekalipun jumlah } \\
\text { keuntungan berlipat atau keadaan }\end{array}$ & $\begin{array}{l}\text { - Jumlah pembagian laba meningkat } \\
\text { sesuai dengan peningkatan jumlah } \\
\text { pendapatan }\end{array}$ \\
\hline
\end{tabular}


- Eksistensi bunga diragukan oleh semua agama
- Tidak ada yang meragukan pembagian nisbah hasil

Sumber: Antonio (2001)

Dalam lembaga pembiayaan syariah suatu pembiayaan tidak akan disetujui sebelum dipastikan beberapa hal pokok, diantaranya adalah objek pembiayaan adalah sesuatu yang halal, tidak menimbulkan kemudharatan bagi masyarakat serta tidak berkaitan dengan tindakan asusila.

\section{Produk Pembiayaan Syariah}

Usaha pertanian yang penuh risiko membutuhkan pembiayaan yang sesuai dengan karakteristiknya dan itu tidak ditemui pada sistem konvensional seperti yang telah dijelaskan sebelumnya. Adapun beberapa produk syariah yang dapat diterapkan pada usaha agribisnis antara lain: mudharabah, musyarakah, muzara'ah, musaqoh, bai' murabahah, bai istishna, bai' as-salm dan rahn.

\section{a. Mudharabah}

Mudharabah merupakan akad kerjasama antara dua pihak, dimana pihak pertama sebagai penyedia modal, sedangkan pihak kedua sebagai pengelola modal. Keuntungan yang diperoleh dalam kerjasama ini dibagi menurut kesepakatan yang dituangkan dalam kontrak dan risiko kerugian ditanggung sepenuhnya oleh pemilik modal, kecuali kerugian diakibatkan oleh kelalaian pengelolah seperti penyelewengan, penyalahgunaan atau bentuk kecurangan lainnya. b. Musyarakah

Musyarakah adalah kerjasama anatra dua pihak atau lebih untuk melakukan kegiata usaha. Masingmasing pihak memberikan kontribusi tertentu dengan kesepakatan keuntungan dan kerugian ditanggung bersama sesuai kesepakatan.

\section{c. Muzara'ah}

Muzara'ah adalah kerjasama pengelolaan pertanian antara pemilik lahan dan penggarap, dimana pemilik lahan menyerahkan lahannya untuk dikelolah sipenggarap dengan imbalan persentase tertentu dari hasil panen.

d. Murabahah

Murabahah adalah jual beli barang pada harga asal dengan tambahan keuntungan yang disepakati.

\section{e. Bai' Salam}

Bai' Salam adalah jual beli dengan ketentuan si pembeli membayar saat ini sedangkan barang akan diterima dimasa akan datang.

f. Bai' Istishna

Bai' Istishna adalah fasilitas penyaluran dana untuk pengadaan barang investasi berdasarkan pesanan.

g. Ar Rahn

Ar Rahn adalah menahan salah satu harta milik sipeminjam sebagai jaminan atas peminjaman yang diterimanya. 
Berikut adalah tabel beberapa alternative pembiayaan syariah untuk sistem agribisnis

Tabel 2. Alternatif pembiayaan syariah untuk sistem agribisnis.

\begin{tabular}{|c|c|c|}
\hline Kegiatan agribisnis & Kendala & Jenis pendanaan \\
\hline Pembukaan lahan & Biaya besar & Murabahah \\
\hline Pengadaan input & Modal di awal & Bai' Muajjal \\
\hline Pengadaan alat dan mesin & Biaya besar, modal di & Ijarah \\
\hline Budidaya & awal & Istisna \\
\hline Panen & Risiko besar & Bai' Salam \\
\hline $\begin{array}{l}\text { Pembukaan } \\
\text { pengolahan }\end{array}$ & $\begin{array}{l}\text { Kepastian jumah dan } \\
\text { mutu }\end{array}$ & $\begin{array}{l}\text { Ijarah wa Istisna } \\
\text { Ijarah wa Istisna }\end{array}$ \\
\hline Pengadaan alat pengolahan & Biaya besar & Mudharabah \\
\hline Pengolahan & Biaya besar & Bai' Salam \\
\hline Pemasaran & Biaya besar & Musyarakah \\
\hline Transfer teknologi & Kepastian harga & Musyarakah \\
\hline Pengembangan SDM & Biaya besar & Qard Hasan \\
\hline Pengadaan biaya hidup & Biaya besar & Takafful \\
\hline \multirow[t]{2}{*}{ Perlindungan asset } & Kontinuitas & \\
\hline & Biaya besar & \\
\hline
\end{tabular}

Sumber: Wulandari dan Suroso (2004)

Sektor agribisnis yang telah dibiayai pembiayaan syariah sudah cukup banyak antara lain: agribisnis tanaman hortikutura (investasi sayuran, bunga potong, salak pondoh) melalui Mudharabah dan Murabahah, agribisnis tanaman pangan (komoditas padi dan jagung) melalui skim Muzara'ah dan Bai' Salam, agribisnis perkebunan (investasi kelapa sawit dan karet) dan agribisnis peternakan (investasi sapi perah dan penggemukan sapi potong) melalui skim Mudharabah.

Beberap hal yang melandasi prospek pembiayaan syariah untuk sektor pertanian adalah sebagai berikut:

a. Karakteristik pembiayaan syariah sesuai dengan karakteristik sektor pertanian, karena memberikan rasa keadilan karena untung dan rugi akan dibagi bersama-sama.

b. Skim pembiayaan syariah sebenarnya sudah dipraktekkan secara luas oleh petani Indonesia yang mirip atau sejalan seperti mudharabah denga maro atau martelu.

c. Luasnya cakupan usaha disektor pertanian.

d. Produk pembiayaan syariah cukup beragam.

e. Tingkat kepatuhan petani, petani kecil dipedesaan umumnya masih menghormati aturan keagamaan dalam kehidupan sehari-hari.

f. Komitmen bank syariah untuk Usaha Kecil dan Menengah.

g. Usaha disektor pertanian merupakan bisnis riil, yang sesuai dengan prinsip bank syariah. 


\section{Tantangan Pembiayaan Syariah}

Pengembangan bank syariah untuk sektor pertanian masih dihadapkan pada beberapa tantangan, pembiayaan bank syariah ke sektor pertanian tidak mengalami peningkatan yang cukup signifikan dari tahun ke tahun, yaitu tercatat pembiayaan di tahun 2006 sebesar 701 milliar, pada tahun 2008 menjadi 1,177 trilliun dan sampai pada akhir 2010 menjadi 1,76 trilliun dari total 91 trilliun penyaluran kredit dari perbankan nasional atau hanya 1,96\% dari total keseluruhan yang disalurkan perbankan syariah.

Adapun beberapa tantangan yang dihadapi oleh perbankan syariah antara lain:

a. Terbatasnya sumber daya manusia diperbankan syariah.

b. Paradigma bank konvensional yang masih kuat.

c. Kurangnya proses sosialisasi bank syariah khususnya produk-produk yang ditawarkan.

d. Terbatasnya jaringan perbankan syariah.

e. Political will yang belum cukup optimal mendukung perbankan syariah.

Tantangan yang dihadapi oleh bank syariah disebabkan umur dari bank syariah yang belum cukup lama kurang lebih 10 tahun dan seiring dengan waktu tantangan yang dihadapi oleh bank syariah dapat terselesaikan.

\section{Simpulan}

Pembiayaan syariah adalah salah satu alternatif pembiayaan yang tepat untuk sektor pertanian yang bisa mengatasi permasalahan utama petani yaitu permodalan untuk pengembangan skala usahanya. Tiga ciri dari pembiayaan syariah adalah bebas bunga, berprinsip bagi hasil dan perhitungan bagi hasil dilakukan setelah periode transaksi berakhir.

Terdapat banyak produk bank syariah yang dapat ditawarkan pada sektor pertanian antara lain seperti mudharabah, musyarakah, muzara'ah, musaqoh, bai' murabahah, bai istishna, bai' as-salam dan rahn. Namun perkembangan bank syariah masih belum signifikan dalam penyaluran kredit kesektor pertanian, hal ini disebabkan bank syariah masih menghadapi beberapa tantangan. Namun seiring dengan waktu tantangan yang dihadapi oleh bank syariah akan dapat diselesaikan sebab keberadaan bank syariah yang masih terbilang belum lama di Indonesia.

\section{Daftar Pustaka}

Anonim. 2011. Kredit Syariah ke Pertanian Diharapkan Naik Dua Kali Lipat. www.suarapembaruan.com.23nov ember2011

Anonim. 2011. Perbankan Syariah Dinilai Cocok Kembangkan Kredit Pertanian. www.republika.co.id.23november $\underline{2011}$

Anonim. 2011 Prospek Pembiayaan Sektor Pertanian oleh Bank Syariah. www.businessnews.co.id.23novem ber2011 
Anonim. 2011. Saatnya Bank Syariah Biayai Sektor Pertanian. www.infobanknews.com.23novem ber2011

Antonio,M. S. 2001. Bank Syariah dari Teori ke Praktek. Gema Insani Press bekerjasama dengan Tazkia Cendekia. Jakarta

Ashari dan Saptana. 2005. Prospek Pembiayaan Syariah untuk Sektor Pertanian. Forum Penelitian Agroekonomi Vol:23 no.2 Desember 2005:132-147. Analisis Sosial Ekonomi Kebijakan Pertanian. Bogor.
Darwanto. 2008. Pengembangan Kredit Sektor Pertanian. Tesis Program Magister Ilmu Hukum Universitas Diponegoro. Semarang.

Sutawi. 2008. Pembiayaan Syariah Pada Usaha Mikro, Kecil dan Menengah Sektor Agribisnis dengan Pola Kemitraan. Jurnal Keuangan dan Perbankan Vol:12 No.3 September 2008:447-458

Wulandari, S dan Suroso, A.L. 2004. Lembaga Keuangan Syariah Alternatif Strategis Memajukan Sektor Agribisnis. Agrimedia, Vol. 9, No. 1 